\title{
Academic achievement among university students: The role of causal attribution of academic success and failure
}

\author{
Asina Christina Rosito \\ Faculty of Psychology, Universitas HKBP Nommensen, Indonesia \\ asina.christina@uhn.ac.id
}

\section{ARTICLE INFO}

Article history

Received 14 March 2019

Revised 11 February 2020

Accepted 14 February 2020

Keywords

academic achievement

causal attribution

locus of causality

personal control

stability

\begin{abstract}
Previous studies have attempted to understand various motivational factors that affect academic achievement. One of the cognitive factors this study focuses on is the causal attribution of academic success and failure. Causal attribution refers to one's perception of the factors that cause learning success and failure. These perceptions encompass three dimensions: locus of causality, stability, and personal control. This study aimed to determine whether causal attribution of academic success and failure predicts academic achievement. 156 students of Universitas HKBP Nommensen across batch years and majors participated in this study. An adapted version of the Causal Dimension Scale was employed as the research instrument. Academic performance was measured using the Grade Point Average (GPA). The simple linear regression analysis results highlight that causal attribution is a significant predictor of academic achievement. Differences in causal attribution between high performing and low performing students were identified. The results imply that personal control is the significant dimension of predicting student's performance, which means that student's beliefs about their capacity to control causal factors, will become a good predictor of their performance. Therefore the more higher students' believe that they are able to control causal factors will enhacnce their academic achievement.
\end{abstract}

\section{Introduction}

One indicator of a country's development is its education performance. PISA (Program for International Student Assessment) is one of the systematic learning assessment models intend on measuring the reading, mathematics, and science ability of students across the Economic Co-operation and Development (OECD) countries. The OECD, including Indonesia, regularly conduct PISA. PISA results can be used as an indicator of the quality of learning as well as to map the learning outcomes of students globally. PISA is conducted by surveying 15-year-old students and testing their abilities, especially in reading, mathematics, and science (OECD, 2019).

The OECD published the latest publication regarding PISA 2018 in December 2019. The findings indicate that Indonesia was still ranked behind other South Asian countries such as Malaysia and Singapore. On average, Indonesia has lower scores for reading, mathematics, and science. Based on OECD (2019), Indonesian students scored 371 in reading, putting Indonesia in rank 72 out of 78 countries. The average reading score was significantly below the overall mean score of the OECD member countries. In mathematics, the mean score was 379 , which placed Indonesia in number 72 out of 78 members. Similarly, the mean score was also significantly below the average score of all members. In terms of science, Indonesia ranked at 70 out of 78 countries with an average score of 396. This score in science remains to be below the overall average science score of the OECD countries. 
The scores mentioned above by PISA indicate the generally low level of learning achievement of Indonesian students compared to students from other countries. It highlights the urgent concern for schools, teachers, parents, education practitioners, as well as the government to analyze the core of students' problems in learning and to formulate general policies that could solve the problems.

Many efforts by the government to enhance national education quality in Indonesia should be highly appreciated. For instance, the Minister Decree of National Education No. 045/U/2002 on Higher Education Curriculum manages the higher education competency element (Republik Indonesia, 2002). Regulation of the Minister of Education and Culture of the Republic of Indonesia No. 73 the year 2013 about National Qualification Implementation Framework (KKNI) in Higher Education (Republik Indonesia, 2013) highlights that the department must arrange learning outcomes and develop academic quality assurance. These outcomes refer to KKNI education by their educational level in arranging, conducting, and evaluating the curriculum. KKNI becomes the reference for faculty department due to its policy, regulation, and guidance of curriculum arrangement. Several curriculum improvements (e.g., specifying learning objectives, developing various teaching methods, using digital learning) have been employed to achieve the expected competencies. These aspects are considered as external factors of the learning process. However, in this case, external factors overlook individual factors (e.g., motivation, intellectual, interest, values, self-regulated learning, academic resilience, and learning strategy). These factors relate to psychological aspects that provide better impact on students' learning.

Motivation in learning has primarily been proven to be a significant factor in predicting academic success and failure. It relates to several questions: What are students' goal in learning? How many hours do students invest in study activities? How many various strategies would they explore to master specific learning materials? Moreover, how persistent would they be when faced with obstacles in learning? (Ormrod, 2008). Motivation powerfully affects academic performance

Motivation cannot be separated from the cognitive and affective aspects involved in directing acts in learning (Ormrod, 2008). One significant cognitive aspect is causal attribution, which predicts academic behaviour (Weiner, 2010). Causal attribution influence three issues: (1) students' expectation of their success and failure, (2) students'effort and persistence in facing difficulties, and (3) decisions they take based on their study and emotional response to success and failure (Ormrod, 2008). Causal attribution is students' perception of the factors that contribute to their success and failure in achieving outcomes (Santrock, 2011). Weiner (2010), the leading theorist of causal attribution in the academic context, proposed that causal attributions are subjective reasons and explanations given by students for why they have failed or succeeded in a given task, test, or an activity. Four main factors were suggested: ability, effort, task difficulty, and luck. For example, once students attribute their academic achievement to lack of efforts, it indicates that they perceive effort as a dynamic condition (unstable), personal (internal locus), and controllable. This perception would lead them to think that they have a higher probability to succeed in a task if they improve their learning. This expectation would be followed by exposure to more effort and develop various learning strategies that lead to an improvement in their performance. Likewise, once students attribute their failure to external factors (e.g., task difficulty, negative attitude of teachers), these could inhibit the development of learner responsibility.

There are at least two reasons that explain the significance of causal attribution in students' learning. First, students' perceived causal attribution influences the crucial psychological dimensions in learning: expectancy, self-efficacy, and affection (Weiner, 1985). Those factors relates to the cognitive aspects in learning which could lead students to behave according to their belief of oneself. For example, when students believe that they fail due to low ability, it could lead to low self-efficacy. On the other hand, when they perceive their effort caused the high score, it could increase their self-efficacy. Second, by then, causal 
attribution relates to students' choices, perseverance, and level of effort in learning. It means that attribution might involve in energizing and directing students' activities in learning. When they perceive that their effort caused their high score, they are more likely to improve their effort for the next tasks, leading to high achievement.

Weiner (2010) conclude that there are three dimensions to causal attribution of academic success and failure: locus of causality, stability, and personal control. Locus of causality dimension correlates with students' perception of their success and failure due to their external or internal factor. Individuals with an internal locus of causality for their success (e.g., ability, effort) tend to show greater pride when achieving this success compared to those that attribute externally (e.g., luck, complex tasks) (Mori, Gobel, Thepsiri \& Pojanapunya, 2010; Santrock, 2011).

The stability dimension correlates with students' perception of causal stability, affecting their expectation of success. If students assume that positive outcome came from stable factors (e.g., intelligence, ability), they would expect success in the future. Thus, when they refer failure to stable factors (e.g., bad luck, lack of effort), they would also expect failure in the future. Likewise, these individuals develop their expectation that they would be successful in the future because they perceive that failure could be changed (Santrock, 2011; Mori et al., 2010).

The personal control dimension relates to students' perception between self-control and emotions that show anger, guilt, compassion, and shyness. Controllable factors are things that could be controlled by students or others (e.g. lack of effort/careless, angry more often). In other side, there are another uncontrollable factors, for instance weather (Mori et al., 2010; Santrock, 2011).

Previous studies attempted to analyze roles and correlation between attribution and academic achievement. Mori et al.(2010) examined Japanese and Thai students' attribution where they tend to focus on external factors (e.g., teachers, class' atmosphere) as the cause of their success, and internal factors (e.g., lack of effort, ability) as the cause of their failure. On the other hand, Boekaerts, Otten, \& Voeten (2003) found differences in terms of causal attribution used by junior high school students when explaining their academic success and failure.

Iksan (2015) in his research on causal attribution affecting academic failure of junior high and high school students, found that $79 \%$ of junior high school students and $87.1 \%$ of high school students attributed their learning failure to laziness and procrastination. Meanwhile, only $21 \%$ of junior high school students and $12.9 \%$ of high school students attributed their failure to external factors (e.g., lack of information support such as when teachers do not address learning materials clearly, friend's negative influence).

In their study, Susetyo \& Kumara (2012) found differences in terms of self-regulated learning seen from causal attribution of success in mathematics, where students believed that their success was supported by effort and ability to have higher self-regulated learning compared to those who believed in easier homework and fate factor. A study conducted by Dasinger (2013) found that students with a higher score in algorithm attributed their success to internal and stable factors.

In another study that involved 260 undergraduate students at the University of Dar es Sallam, Tanzania (Mkumbo \& Amani, 2012) found that high-performing students tend to attribute their performance to internal and controllable factors compared to low-performing students. In other word, success was attributed to internal and controllable factors, and failure was attributed to external and uncontrollable factors.

Based on the literature review, it can be assumed that causal attributions do affect students' academic achievement. Most existing studies on causal attribution have explored this phenomenon in high school students with very few involving undergraduate students. Additionally, most of the previous studies were taken place in the context of students' causal attribution in English learning course (Erten \& Burden, 2014; Gabillon, 2013; Gobel, Thang, 
Sidhu, Oon, \& Chan, 2013; Hashemi \& Zabihi, 2011; Photongsunan, 2014; Sahinkarakas, 2011; Zohri, 2011). Very few have explored causal attribution as an integrated perception of students' success and failure. Moreover, no study related to this topichas been conducted in North Sumatera, Indonesia. Based on this fact, this study aimed to investigate undergraduate students from a private university in North Sumatera perceive academic success and failure. Specifically, the purpose of this study is to determine whether causal attribution of academic success and failure affect the academic achievement of undergraduate students. It is hypothesized that causal attribution could predict students' academic achievement.

\section{Method}

\section{Research Participants}

The participants consist of 156 active students of Universitas HKBP Nommensen, Medan, aged between 17 to 24 years old. Among them, 59 are male students $(37.8 \%)$ and 97 female students $(62.2 \%)$. The convenience sampling technique was used in this study. Data was collected once participants agreed to volunteer in this study as respondents. They were also informed that data collected from them would be used only for research purpose.

\section{Instrument}

This study used the attribution towards academic success and failure scale, an adapted version from The Causal Dimension Scale (Russell, 1982). The latter was based on the causality dimension proposed by Weiner (1979). For the adaptation process, the researcher and one colleague translated the scale. Next, several students provided feedback regarding the translated scale to measure their understanding of the adapted version.

The Causal Dimension Scale consists of eight different achievement situations, some depicting academic success and failure. In total, there are eight different scenarios: failure attributed to lack of ability, failure attributed to task difficulty, success attributed to good luck, success attributed to high effort, failure attributed to bad mood, success attributed to good lecturer, failure attributed to low effort, and failure attributed to bad friends. Each situation is followed by a semantic differential scale. The following is an example of one of the situations (i.e., failure due to lack of ability): "Imagine that you have received a very low score in a class that is very important to you. You feel the reason you received this low score is your lack of ability in the subject."

Students evaluated the cause of the success or failure outcome on nine semantic differential scales while imagining themselves in each situation. An example of one of the items assessing the locus of causality dimension is "Reflects on you-reflects your situation." Participants were asked to rate the extent to which they felt the cause was internal or external on this scale, by circling a number from 1 (one) to 6 (six). An example of one of the items assessing the stability dimension was "Permanent-temporary." An example of one of the items assessing the controllable dimension was "Uncontrollable by you or other peoplecontrollable ". In total, each student made 72 ratings, evaluating the eight causal attributions on all nine semantic differential scales. A higher score indicate that the cause is perceived as internal, stable, and controllable. Table 1 summarizes the dimensional classification for some identified causal attributions.

The reliability of this scale ranges from moderate to high. Each dimension of the scale has an Alpha Cronbach coefficient that ranged from .511 to .855 (Russel \& Mcauley, 1987). The reliability tests show that each dimension in the scale, specifically referring to each situation, achieved an Alpha Cronbach coefficient that ranged from .558 to .753. These results indicate that the reliability of this scale ranges from moderate to high. 
Table 1

Dimensional Classification Scheme for Causal Attributions

\begin{tabular}{llll}
\hline Attribution & & Dimension & \\
\cline { 2 - 4 } & Locus & Stability & Personal control \\
\hline Ability & Internal & Stable & Uncontrollable \\
Effort & Internal & Unstable & Controllable \\
Luck & External & Unstable & Uncontrollable \\
Task difficulty & External & Stable & Uncontrollable \\
Strategy & Internal & Unstable & Controllable \\
Interest & Internal & Unstable & Controllable \\
Teacher influence & External & Stable & Uncontrollable \\
Family influence & External & Stable & Uncontrollable \\
\hline
\end{tabular}

Source: Weiner (1979), Russel (1982) \&Photsongsunan (2014)

Academic achievement was measured based on the odd-semester (2017/2018) GPA reported by the participants in the questionnaire. GPA is widely used in previous studies related to academic achievement in tertiary education because it is considered as one of the primary indicators of college success based on a systematic assessment of students' learning process (Feldman \& Kubota, 2014). Additionally, it reflects the level of achievement of a student compared to others.

\section{Data analysis}

To test the hypothesis of this study, descriptive and simple linear regression analysis were conductedwith Statistical Program for the Social Sciences (SPSS) for Windows version 20. Descriptive analysis was used to describe the GPA categories and identify the mean and standard deviation scores of each research variable. Simple linear regression analysis was conducted to test whether causal attribution could be a good predictor of academic achievement.

\section{Results}

The main purpose of this study was to examine the influence of causal attribution of academic success and failure towards academic achievement. Table 2 depicts the brief descriptive analysis results before the main findings are further discussed.

Table 2

Participants' Demographic Data

\begin{tabular}{crrlrr}
\hline Variables & Frequency & Percentage & Variables & Frequency & Percentage \\
\hline Age & & & Year of study & & \\
17 & 1 & $6 \%$ & First year & 50 & $32.1 \%$ \\
18 & 15 & $9.6 \%$ & Second year & 10 & $44.9 \%$ \\
19 & 45 & $28.8 \%$ & Third year & 19 & $10.9 \%$ \\
20 & 39 & $25 \%$ & Fourth year & & $2.2 \%$ \\
21 & 31 & $19.9 \%$ & GPA & 17 & $10.9 \%$ \\
22 & 21 & $13.5 \%$ & Satisfactory $(2.00-2.75)$ & 99 & $63.5 \%$ \\
23 & 2 & $1.3 \%$ & Very satisfactory $(2.76-3.50)$ & 40 & $25.6 \%$ \\
24 & 2 & $1.3 \%$ & Cum Laude $(3.51-4.0)$ & & \\
\hline
\end{tabular}

Table 2 shows that the participants' age range between 17 to 24 years old, with the majority being 19 years old (28.8\%). Also, almost half of the participants (44.9\%) are in their second year of study. Based on the GPA categories, more than half of the participants $(63.5 \%)$ achieve a very satisfactory predicate. 
Table 3

Multiple Regression Analysis for Causal Attribution Dimensions as Predictors of GPA

\begin{tabular}{lcl}
\hline Dimension & $\beta$ & $p$ \\
\hline Constant & 2.661 & \\
Locus of causality & .109 & .231 \\
Stability & -.116 & .150 \\
Personal control & .226 & $.016^{*}$ \\
$R^{2}$ & .091 & \\
$F$ & $5.064 * *$ & \\
$* p<.05 . * * p<.01, \mathrm{~N}=156$ & &
\end{tabular}

Table 3 shows the results of the regression analysis that test the primary hypothesis, to explore whether causal attribution predicts academic achievement. A multiple regression analysis was conducted using enter mode by viewing each of the causal attribution dimension (i.e., locus of causality, stability, personal control) as an independent dimension.

Based on the multiple regression analysis, as shown in Table 3, it can be concluded that causal attribution dimensions, as a model of regression, could be a good predictor of academic achievement $\left(R^{2}=.091, F(1.154)=5.064, p<.01\right)$. This finding indicates the effective contribution of causal attribution towards GPA was about $9.1 \%$.

Additionally, as can be seen in Table 3, only personal control dimension significantly predicts GPA. In other words, participants' sense of control upon a task or situation, could be the highest' causal dimension predictor of their level of achievement in the academic field.

Table 4

Causal Attribution Dimensions of Academic Success Based on GPA Category

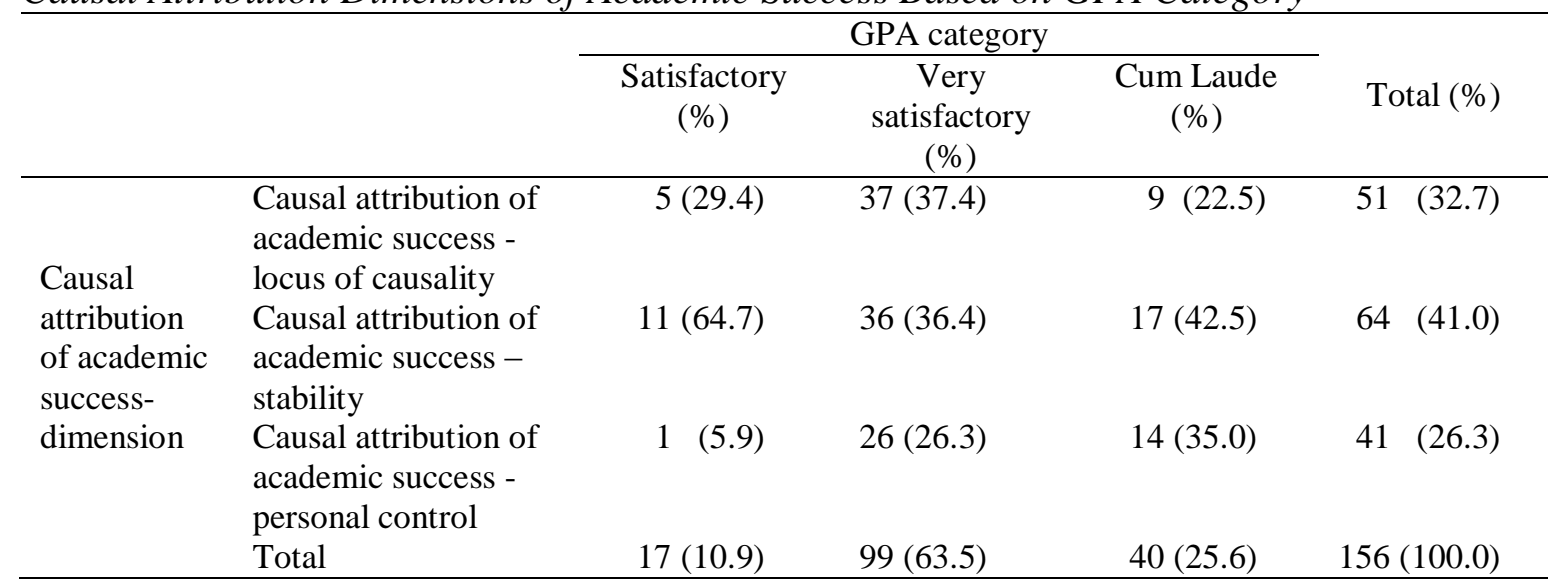

Additional data analysis was conducted to explore and describe the participants' attribution based on their level of academic achievement. The results of the descriptive analysis can be seen in Table 4. Out of 17 students (10.9\%) with a satisfactory predicate, most assumed that their success was attributed to stable factors $(64.7 \%)$. There were 99 participants $(63.5 \%)$ with a very satisfactory predicate, and the majority (37.4\%) attributed their success to an internal locus of causality. Among 40 students with highest performance category, most of them $(42.5 \%)$ believed that their success caused by stable factors.

Table 5 shows the overview of causal attribution of academic failure dimensions for each GPA category. Out of 17 students with a satisfactory predicate, most attributed their failure to stable factors (64.7\%). There were 40 students $(40.4 \%)$ with a very satisfactory predicate who attributed their failure to stable factors. A different finding was found in 40 students with cum laude predicate, in which 15 of them (37.5\%) attributed academic failures to personal control. 
Table 5

Causal Attribution Dimensions of Academic Failure Based onGPA Category

\begin{tabular}{|c|c|c|c|c|c|}
\hline & \multicolumn{3}{|c|}{ GPA category } & \multirow[b]{2}{*}{ Total (\%) } \\
\hline & & $\begin{array}{l}\text { Satisfactory } \\
(\%)\end{array}$ & $\begin{array}{l}\text { Very } \\
\text { satisfactory } \\
(\%)\end{array}$ & $\begin{array}{c}\text { Cum laude } \\
(\%)\end{array}$ & \\
\hline \multirow{4}{*}{$\begin{array}{l}\text { Causal } \\
\text { attribution } \\
\text { of academic } \\
\text { failure- } \\
\text { dimension }\end{array}$} & $\begin{array}{l}\text { Causal attribution of } \\
\text { academic failure -locus }\end{array}$ & $4(23.5)$ & $39(39.4)$ & $12(30.0)$ & $\begin{array}{ll}55 & (35.3)\end{array}$ \\
\hline & $\begin{array}{l}\text { Causal attribution of } \\
\text { academic failure - } \\
\text { stability }\end{array}$ & $11(64.7)$ & $40(40.4)$ & $13(32.5)$ & $64 \quad(41.0)$ \\
\hline & $\begin{array}{l}\text { Causal attribution of } \\
\text { academic failure - } \\
\text { personal control }\end{array}$ & $2(11.8)$ & $20(20.2)$ & $15(37.5)$ & $37 \quad(23.7)$ \\
\hline & Total & 17 (10.9) & 99 (63.5) & $40(25.6)$ & $156(100.0)$ \\
\hline
\end{tabular}

\section{Discussion}

Our findings conclude that the main hypothesis of this study is confirmed, that is causal attribution, as reflected in its three dimensions, could predict academic achievement. In the academic context, causal attribution is defined as an individual's perception of the causes of his or her academic achievement, both success and failure. Therefore, causal attribution is one of the cognitive aspects of the process of directing individuals to conduct various learning choices. Several factors could influence success or failure: ability, effort, luck, task difficulty, strategy, interest, teacher influence and family influence (Photongsunan, 2014; Russel, 1982; Weiner, 1979). Those factors could be analyzed in three dimension: locus of causality, stability, and personal control (Weiner, 1985). Locus of causality relates to whether the causal factors are internal (within a person) or external (outside a person). Some internal factors include abilities, effort, strategy, and interest. Meanwhile, external factors include luck, task difficulty, teacher influence, and family influence. The dimension of stability is related to the possibility of changes from time to time on these causal factors. For example, effort is an unstable factor because it can change at certain times. In the middle of a competition, students will give more effort in learning than usual or vice versa. The dimension of personal control refers to whether the causal factor could be controlled or not by students. For example, the effort is a controllable factor because individuals can direct and regulate how much effort they would give in carrying out specific tasks.

This study's participants tended to interpret that both the success and failure situations experienced were caused by the effort in learning. It means that students interpret that the high or low grades in learning are determined by themselves (internal), could change over time (unstable), and could be controlled by them in terms of how much effort they would put into learning. When an individual interprets his or her success or failure as a result of high or low effort in learning, they believe that the results of study could be improved when they put more effort. They also believe that they could alter the causes, influencing their performance (Mkumbo \& Amani, 2012). Previous study found that high achiever students tend to attribute their success to the high level of effort they put into it (Mkumbo \& Amani, 2012).Students perception of causal factors of their learning performance has a crucial effect on their expectation of success or failure in studying, future choices regarding learning strategies, the level of effort they would put into learning, and how they would feel about success or failure (Ormrod, 2008).

Our findings are in line with a study by Hashemi \& Zabihi (2011) who found a significant relationship between students attribution of success and failure and their performance in English language test. Research by Muwonge \& Ssenyonga (2015) also found 
similar results in that there is a significant correlation between causal attribution of success and failure with GPA for undergraduate students of a University in Uganda.

Causal attribution plays a role in students' self-regulated learning process. In his theory of self-regulated learning, Pintrich (Schunck, 2005) stated that there is a monitoring stage where individuals make reflections, judgments, and attributions to their learning performance. By evaluating the causal factors of their performance, students become more engaged in a deeper reflection of their learning behavior. This process of causal attribution is a crucial role for the next step of their learning because, by then, it becomes the basis for making further goals and self-directed learning behavior. In other words, causal attribution influences the next learning choices that students will make. When individuals believe that their failure is caused by internal, stable, and uncontrolled factors (e.g., abilities), they will assume that their effort cannot change the outcome. In other words, they believe that their low ability is permanent. As a result, very minimal changes will be made in their learning choices and they would tend to have low self-efficacy. These choices in learning behavior would lead to low academic performance.

The dynamic in academic attribution could also be explained by its' role towards students' level of persistence (Lei, 2009). Lei stated that, when students attribute their academic success to factors that are internal, unstable, and controllable, they would be more persistent in accomplishing academic tasks. Additionally, students exhibit more confidence in their ability to accomplish various academic tasks, reflecting their high level of selfefficacy.

This current study shows that the significant dimension in predicting academic achievement is personal control. Although personal control dimension cannot be perceived separately from the other two dimensions, these results indicate the important role of students' perception of their ability to change the identified causal factors.

The findings of this study also indicate that students, across GPA categories, are more likely to attribute their good grades to stable factors. In other words, students perceive success to be related to factors that cannot be changed, such as ability and task difficulty. When students believe the causes of their performance outcome to be stable, it increases their belief of receiving the same outcome in the future. In contradiction, if students believe that unstable factors influence their academic achievement, it increases the likelihood of students modifying their effort to achieve a different outcome (Weiner, 1985). This result is consistent with a study conducted by Dasinger (2013), who found that students with high scores in algorithm attributed their success to stable factors. Concerning these findings, when students believe that unchangeable factors are influencing their academic performance, it could hinder their motivation. For example, if students believe they achieve high grades because of their ability, they could underestimate the role of effort in learning. If students with low grades believe that their low ability or intellectual capacity causes it, they would expect similar resultsin the future, potentially affecting their effort and enthusiasm in learning. Dweck (Sukariyah \& Assaad, 2015) suggested encouraging students to attribute their failures to unstable factors (e.g., effort). This type of attribution would booststudents' effort, eventually improvingtheir academic achievement.

Meanwhile, different patterns between GPA categories were found for how students attribute their failures. Participants in cum laude category mostly believe that their low score is related to controllable factors. It means that higher performance students' see their failure to mainly be related to factors that they can control (e.g.,skill/efficacy, strategy, interest) (Gobel et al., 2013). This finding is consistent with Iksan (2015) that most participants (79\% of junior high school students and $87.1 \%$ of high school students) attributed their failure of learning performance to laziness and procrastination that can be controlled or influenced by themselves or others. On the other side, students in satisfactory and very satisfactory categories are more likely to attribute their failure to stable factors such as ability or task difficulty. 
Some limitations of this study were identified. First, since the focus of this study was causal attribution in terms of its dimensions, data that described the various causal factors perceived by students had not been identified. Further study using a more comprehensive measurement is suggested to reveal what factors cause success and failure in learning, according to the students. Second, because the majority of the participants in this study were from Batak, one of the tribes in North Sumatera, the results of this study may not be generalizable to other ethnic groups. In the future, studies that involve various demographic background of participants are encouraged.

\section{Conclusion}

Students' belief about causal factors for both their academic success and failure, contributes significantly to their academic achievement. By giving meaning to the factors that contribute to both academic success and failure, students are directed to make relevant learning choices. Our findings imply that attribution has a significant role in directing students' effort in studying and achieving better academic performance, especially the personal control dimension which was found as the most significant aspect in predicting students' performance. Students may focus on factors that are controllable and unstable (e.g., effort, strategies) compared to uncontrollable and stable factors (e.g., ability, task difficulty). Appropriate causal attribution could improve their learning effort and learning strategies, leading to better performance. Teachers may assist students in identifying students' beliefs about the causes of their success and failure in various academic activities within the three dimensions of causal attributions. Afterwards, teachers may help students in reframing their perception of those causal factors in terms of categorized which factor that they have control on it, which factor they do not have. For controlled factor, such as effort, they are encouraged to increase their effort ini learning by trying to find meaning in their study. For uncontrolled factor such as, difficulty of tasks, students can be taught to develop effective strategies in learning. Afterwards, it could be predicted that they academic performance will be better.

\section{References}

Boekaerts, M., Otten, R., \& Voeten, R. (2003). Examination performance: Are student's causal attributions school-subject specific. Anxiety, Stress \& Coping, 16(3), 331-342. https://doi.org/10.1080/1061580031000095470

Dasinger, J. A. (2013). Causal attributions and student success in developmental mathematics. Journal of Developmental Education, 36(3), 2-12. Retrieved from https://files.eric.ed.gov/fulltext/EJ1067285.pdf

Erten, I. H., \& Burden, R. L. (2014). The relationship between academic self-concept, attributions, and L2 achievement. System 42, 391-401. https://doi.org/10.1016/j.system.2014.01.006

Feldman, D. B., \& Kubota, M. (2014). Hope, self-efficacy, optimism, and academic achievement: Distinguishing constructs and levels of specificity in predicting college grade-point average. Learning and Individual Differences, 37, 210-216. https://doi.org/10.1016/j.lindif.2014.11.022 
Gabillon, Z. (2013). Language learning beliefs from an attributional perspective. Procedia Social and Behavioral Sciences, 106, 1697-1711. https://doi.org/10.1016/j.sbspro.2013.12.193

Gobel, P., Thang, S. M., Sidhu, G. K., Oon, S. I., \& Chan, Y. F. (2013). Attributions to success and failure in English language learning: A comparative study of urban and rural undergraduates in Malaysia. Asian Social Science, 9(2), 53-60. https://doi.org/10.5539/ass.v9n2p53

Hashemi, M. R., \& Zabihi, R. (2011). Students' attributional beliefs in success or failure and their performance on the interchange objective placement test. Theory and Practice in Language Studies, 1(8), 954-960. https://doi.org/10.4304/tpls.1.8.954-960

Iksan, M. (2015). Atribusi kegagalan berprestasi pada siswa SMP dan SMA (Failure achievement attribution among junior and senior high school students). Jurnal Psikologi Tabularasa, 10(2), 172-185.

Lei, C. (2009). On causal attribution of academic achievement in college students. Asian Social Science, 5(8), 87-96. https://doi.org/10.5539/ass.v5n8p87

Mkumbo, K. A. K., \& Amani, J. (2012). Perceived university students' attributions of their academic success and failure. Asian Social Science, 8(7), 247-255. https://doi.org/10.5539/ass.v8n7p247

Mori, S., Gobel, P., Thepsiri, K., \& Pojanapunya, P. (2010). Attributions for performance: A comparative study of Japanese and Thai university students. JALT Journal, 32(1), 528.

Muwonge, C. M., \& Ssenyonga, J. (2015). Academic performance, causal attributions and hope to complete studies among university students. Journal of Education, Psychology, and Social Science, 3(1), 50-56.

OECD. (2019). PISA 2018 Results (Volume I): What Students Know and Can Do. https://doi.org/10.1787/5f07c754-en

Ormrod, J. E. (2008). Psikologi pendidikan (Educational psychology) Jilid 2. Jakarta: Penerbit Erlangga.

Photongsunan, S. (2014). Investigating Thai university students' attributions of English learning success: An international university context. Paper presented at the WEI International Academic Conference, Vienna, Austria.

Republik Indonesia. (2002). Keputusan Menteri Pendidikan Nasional Republik Indonesia Nomor 45 Tentang Kurikulum Inti Pendidikan Tinggi (Decree of The Minister of National Education Number 45 on Higher Education Core Curriculum). Jakarta: Kementerian Pendidikan Nasional Republik Indonesia.

Republik Indonesia. (2013). Peraturan Menteri Pendidikan Dan Kebudayaan Republik Indonesia Nomor 73 Tahun 2013 Tentang Penerapan Kerangka Kualifikasi Nasional Indonesia Bidang Pendidikan Tinggi (Regulation of The Minister of Education and Cultural Number 73 Year 2013 on Application. Jakarta: Kementerian Pendidikan dan Kebudayaan Republik Indonesia.

Russel, D. (1982). The causal dimension scale: A measure of how individuals perceive causes. Journal of Personality and Social Psychology, 42(6), 1137-1145. 
https://doi.org/10.1037/0022-3514.52.6.1248

Russel, D., \& Mcauley, E. (1987). Measuring causal attributions for success and failure: A comparison of methodologies for assessing causal dimensions. Journal of Personality and Social Psychology, 52(6), 1248-1257. https://doi.org/10.1037/00223514.52.6.1248

Sahinkarakas, S. (2011). Young students' success and failure attributions in language learning. Social Behavior and Personality, 39(7), 879-886. https://doi.org/10.2224/sbp.2011.39.7.879

Santrock, J. W. (2011). Educational psychology, $5^{\text {th }}$ edition. New York: McGraw-Hill Companies.

Schunck, D. H. (2005). Self-regulated learning: The educational legacy of Paul R. Pintrich. Educational Psychologist, 40(2), 85-94.

Sukariyah, M. B., \& Assaad, G. (2015). The effect of attribution retraining on the academic achievement of high school students in Mathematics. Procedia-Social and Behavioral Sciences, 122, 345-351. https://doi.org/10.1016/j.sbspro.2015.02.356

Susetyo, Y. F., \& Kumara, A. (2012). Orientasi tujuan, atribusi penyebab, dan belajar berdasar regulasi diri (Goal orientation, causal attribution, and self-regulated learning). Jurnal Psikologi, 39(1), 95-111. https://doi.org/10.22146/jpsi.6969

Weiner, B. (1979). A theory of motivation for some classroom experiences. Journal of Educational Psychology, 71, 3-25. https://doi.org/10.1037/0022-0663.71.1.3

Weiner, B. (1985). An attributional theory of achievement motivation and emotion. Psychological Review, 92, 548-573. https://doi.org/10.1037/0033-295X.92.4.548

Weiner, B. (2010). Attribution theory. International Encyclopedia of Education, 6, 559-563. https://doi.org/10.1002/9780470479216.corpsy0098

Zohri, A. (2011). Causal attributions for failure and the effect of gender among Moroccan EFL university students. English Language Teaching, 130-137. https://doi.org/10.5539/elt.v4n4p130 